\title{
$\begin{array}{r}\text { WAGENINGEN } \\ \text { UNIVERSITY \& RESEARCH } \\ \hline\end{array}$
}

\section{Red clover varieties of Mattenklee type have higher production, protein yield and persistence than Ackerklee types in grass-clover mixtures}

Hoekstra, N. J., De Deyn, G. B., Xu, Y., Prinsen, R., \& van Eekeren, N.

This article is made publically available in the institutional repository of Wageningen University and Research, under article $25 \mathrm{fa}$ of the Dutch Copyright Act, also known as the Amendment Taverne.

Article 25 fa states that the author of a short scientific work funded either wholly or partially by Dutch public funds is entitled to make that work publicly available for no consideration following a reasonable period of time after the work was first published, provided that clear reference is made to the source of the first publication of the work.

For questions regarding the public availability of this article, please contact openscience.library@wur.nl.

Please cite this publication as follows:

Hoekstra, N. J., De Deyn, G. B., Xu, Y., Prinsen, R., \& van Eekeren, N. (2018). Red clover varieties of Mattenklee type have higher production, protein yield and persistence than Ackerklee types in grass-clover mixtures. Grass and Forage Science, 73(2), 297-308. https://doi.org/10.1111/gfs.12307 


\title{
Red clover varieties of Mattenklee type have higher production, protein yield and persistence than Ackerklee types in grass-clover mixtures
}

\author{
N. J. Hoekstra ${ }^{1,3}$ \\ G. B. De Deyn ${ }^{2}$ \\ $\mathrm{Y} . \mathrm{Xu}^{2}$ \\ R. Prinsen ${ }^{2}$ \\ N. Van Eekeren ${ }^{1}$
}

${ }^{1}$ Louis Bolk Institute, Driebergen, The Netherlands

${ }^{2}$ Department of Soil Quality, Wageningen University, Wageningen, The Netherlands

${ }^{3}$ Radboud University, Department of

Experimental Plant Ecology,

Heijendaalseweg 135, 6525 AJ, Nijmegen,

The Netherlands

Correspondence

N. J. Hoekstra, Louis Bolk Institute,

Driebergen, The Netherlands.

Email: n.hoekstra@louisbolk.nl

Funding information

ZuivelNL (Dutch Dairy Board); Stuurgroep

Landbouw Innovatie Noord-Brabant

\begin{abstract}
Dairy farmers have increased interest in multiyear red clover-ryegrass ley pasture swards because of their high productivity and protein concentration but the adoption of such mixtures has been restricted because of poor persistency of many red clover cultivars currently used. We aimed (i) to assess dry-matter yield (DMY), persistence and nutritive value of four Mattenklee and four Ackerklee cultivars and (ii) to investigate the underlying plant morphological traits. We conducted a 4-year field experiment with red clover-ryegrass mixtures, in combination with a short-term pot experiment in which the red clover cultivars were grown both in monoculture and in mixture with Lolium perenne $\mathrm{L}$. In the field, Mattenklees showed higher production (on average $42 \%$ higher) and clover content (on average 34\% higher) in the third and fourth year of production compared to Ackerklees. In the fourth year, Mattenklees had slightly lower digestibility and lower protein concentration compared to Ackerklees cultivars; however, the digestible DMY and the protein yield were higher for Mattenklees. Both persistence and nutritive value of the different red clover cultivars were closely correlated with plant morphological traits. For stem length, there was close correlation $(r>.77)$ between the results from the pot experiment and the field experiment, suggesting that stem length may be an important trait for plant breeding.
\end{abstract}

KEYWORDS

breeding, morphology, nutritive value, plant traits, Trifolium pratense $\mathrm{L}$.

\section{1 | INTRODUCTION}

In recent decades, the European forage sector has been confronted with new challenges. In order to reduce the adverse effects of agricultural practices on the environment, the European Union (EU) has implemented a series of guidelines to its member states (e.g., the EU Nitrates Directive and Drinking Water Directive). These directives have resulted in a limitation in the amount of nutrients (particularly nitrogen) that can be applied to grassland. As a result, forage legumes with their ability for symbiotic $\mathrm{N}_{2}$ fixation are playing an increasingly important role in grassland forage production in the dairy sector (Gierus, Kleen, Loges, \& Taube, 2012; Halling, Topp, \& Doyle, 2004;
Hejduk \& Knot, 2010; Lüscher, Mueller-Harvey, Soussana, Rees, \& Peyraud, 2014; Mela, 2003). Among legume forages, red clover (Trifolium pratense L.) ranks second worldwide after alfalfa (Medicago sativa L.) based on the amounts of seed produced, marketed and cultivar availability (Boller, Schubiger, \& Kölliker, 2010), and it has a long history of importance in central Europe (Hejduk \& Knot, 2010); In the north-west of Europe especially, red clover is gradually gaining momentum as part of a rotation scheme based on grass-clover and maize silage, although white clover (Trifolium repens L.) is the dominant forage legume species in this region (Gierus et al., 2012).

In the Netherlands, there is an increasing interest in red clover for ley pastures by dairy farmers, who see its value and potential in 
terms of symbiotic nitrogen fixation, protein concentration and production capacity (lepema, van Eekeren, \& van Dongen, 2006). One of the main constraints that restricts the adoption of red clovergrass mixtures is the poor persistency of the red clover cultivars that are currently used by farmers (lepema et al., 2006). These farmers are increasingly specialized in dairy production, and make less use of arable crops than can be sown in rotation with the red clover, and would like to extend these leys by more than the 2 or 3 years that are feasible with the currently used cultivars. Extending the duration of the clover ley would reduce costs for seeding and also have positive effects on carbon sequestration and soil biodiversity (Van Eekeren et al., 2008).

Although a natural decline in plant populations is typical for clover swards (Frame, Charlton, \& Laidlaw, 1998), disease infestation, pest attacks, improper management, winter kill and poor competitiveness have all been reported as important factors leading to poor persistence (Boller et al., 2010; Taylor, 2008; Taylor \& Quesenberry, 1996). In the 20th century, considerable efforts were made in red clover breeding programmes and research which aimed to improve red clover resistance to various fungal and virus diseases, pests and nematodes (Christensen, Koga, Tsukiboshi, \& Uematsu, 1994; Coulman \& Lambert, 1995; Delclos, Mousset-Déclas, \& Raynal, 1997; Marum, Smith, \& Grau, 1994; Page, Dulclos, Aubert, Bonavent, \& Mousset-Declas, 1997; Quesenberry, Baltensperger, Dunn, Wilcox, \& Hardy, 1989; Rufelt, 1985). Although forage production and disease resistance of many red clover cultivars have been improved considerably during the last decades (Marshall, Lowe, \& Vale, 2012), persistency of cultivars remains an issue. In Switzerland, highly persistent and locally adapted red clover landraces, the so-called Mattenklees, show a high level of survival after three growing seasons in swards mixed with grass (as opposed to the traditional "Ackerklees" or European field clover cultivars) (Boller, 2000; Lehmann \& Briner, 1998). Swiss Mattenklee cultivars are characterized by an early time of flowering, high resistance to anthracnose or crown rot and an improved persistence resulting particularly in a high forage yield in the second production year. However, Mattenklee cultivars often show a lower forage yield in the first production year, particularly for the first cut, compared with Ackerklee cultivars (Lehmann \& Briner, 1998).

Red clover is mainly grown in mixtures with grasses for a number of reasons, including nutritional composition of the forage, higher $\mathrm{N}$ fixation efficiency (Nyfeler, Huguenin-Elie, Suter, Frossard, \& Lüscher, 2011), higher production, lower contamination with soil during the harvest and positive effects on soil quality (Mytton Cresswell, \& Colbourn, 1993; Van Eekeren et al., 2009). The red clover proportion is an important feature for the forage quality as well as agronomic performance of binary mixtures with legumes and grasses (Kleen, Taube, \& Gierus, 2011) and is determined by the competitive ability of red clover and the companion grass. Important plant traits in this respect include plant height and leaf area (competition for light), $\mathrm{N}$-fixating capacity, plant survival and persistence.

There has been some effort to link easily measurable morphological characteristics to persistence. For example, Herrmann, Boller,
Studer, Widmer, and Kölliker (2008) showed that persistence is highly positively correlated with stem length. Also, flowering responses have been used as an indicator for persistence, with early flowering suggesting a higher persistence (Annicchiarico \& Pagnotta, 2012; Ford \& Barrett, 2011). In addition to differences in dry-matter yield (DMY) and production, red clover cultivars may differ in nutritional quality, e.g., protein concentration and digestibility (Frame, Harkess, \& Hunt, 1972).

The objectives of this research were (i) to assess the DMY, persistence, nutritive value (crude protein [CP] concentration, digestibility) and total $\mathrm{N}$ uptake of four Mattenklee and four Ackerklee cultivars grown in mixture with perennial ryegrass and (ii) to increase our insight into differences in persistency, competitive ability and nutritive value by relating them to plant morphological traits including stem length, leaf/stem ratio and plant density. To this end, we conducted a 4-year small-plot field experiment with red clover-grass mixtures in combination with a short-term pot experiment in which red clover was grown both in monoculture and in mixture with Lolium perenne L. We hypothesized that (i) Mattenklee cultivars grown in mixture with perennial ryegrass would show higher clover and total herbage yield compared with Ackerklee cultivars in the third and fourth production year and (ii) increased persistence can be correlated with plant morphological traits.

\section{MATERIALS AND METHODS}

\subsection{Field experiment}

\subsection{1 | Experimental set-up}

The field experiment was established in August 2011 at an organic dairy farm located at Esbeek, the Netherlands $\left(51^{\circ} 26^{\prime} 44^{\prime \prime} \mathrm{N}, 5^{\circ} 7^{\prime} 13^{\prime \prime}\right.$

E). The mean annual temperature at the nearby weather station in Eindhoven was $10.9^{\circ} \mathrm{C}$, and yearly precipitation was $751 \mathrm{~mm}$ in the years 2011 to 2015 (for more details, see Table S1). The field had been used previously for arable production, with a crop rotation of green beans, potato and lettuce, operating in accordance with organic crop cultivation rules in the Netherlands (Skal). The field received 20 tons/ha of farmyard manure in spring 2011 (supplying an estimated $104 \mathrm{~kg} \mathrm{~N}$-total ha ${ }^{-1}, 78 \mathrm{~kg} \mathrm{P}_{2} \mathrm{O}_{5} \mathrm{ha}^{-1}, 268 \mathrm{~kg} \mathrm{~K}_{2} \mathrm{O} \mathrm{ha}^{-1}$ ), in combination with $1 \mathrm{t} / \mathrm{ha}$ of ground limestone to maintain soil $\mathrm{pH}$ at a $\mathrm{pH}-\mathrm{KCl}$ of 5.5 . The soil texture was loamy sand with $2 \%$ clay, $18 \%$ silt and $76 \%$ sand. Soil fertility characteristics in the $0-$ to $10-\mathrm{cm}$ soil layer were summarized as follows: soil $\mathrm{pH}-\mathrm{KCl}, 5.4$; soil organic matter, 3.9\%; CEC, $50 \mathrm{mmol} / \mathrm{kg}$; total nitrogen, $0.13 \%$; $\mathrm{C} / \mathrm{N}$ ratio, 17 ; available $\mathrm{P}\left(\mathrm{P}-\mathrm{CaCl}_{2}\right), 0.9 \mathrm{mg} \mathrm{P} \mathrm{kg}^{-1}$; available $\mathrm{K}, 74 \mathrm{mg} \mathrm{K} \mathrm{kg}{ }^{-1}$.

The trial was arranged in a randomized block design with four replicates. Eight red clover (Trifolium pratense L.) cultivars, namely four Ackerklee landraces (cv. Avanti, Lemmon, Maro and Taifun) and four Mattenklee landraces (cv. Fregata, Larus, Milvus and Pavo), were selected. Five of the eight cultivars were tetraploid (Avanti, Maro, Taifun, Fregata and Larus) and three were diploid (Lemmon, Milvus and Pavo) cultivars. The red clover was sown in mixture with diploid perennial ryegrass (Lolium perenne L., cv. Mathilde, $30 \mathrm{~kg}$ 
ryegrass seed $\mathrm{ha}^{-1}$ ) in plots of $4 \mathrm{~m} \times 8 \mathrm{~m}$. In order to achieve an equal red clover plant density for the eight red clover cultivars, seeding rates for the different cultivars were adjusted to 270 viable seeds $\mathrm{m}^{-2}$ based on 1,000 seed weight and germination rate (Table S2). The germination rate of most cultivars was above $90 \%$, which confirmed that there was a limited number of hard seeds. Plots were sown with a pneumatic sowing machine specifically designed for sowing experimental plots with different seeding rates, and the sowing depth was $1.5 \mathrm{~cm}$.

The trial was managed with a four-cut regime (cut in May, July, August and October) under rainfed conditions during 4-year experiment (2012-2015). Throughout the experiment, plots received $25 \mathrm{~m}^{3} /$ ha of cattle slurry before the first cut, and $300 \mathrm{~kg} / \mathrm{ha}$ potassium sulphate $\left(\mathrm{K}_{2} \mathrm{SO}_{4}\right)$ divided between the second and third cuts (90 kg N-total ha ${ }^{-1}, 17 \mathrm{~kg} \mathrm{P} \mathrm{ha}^{-1}, 130 \mathrm{~kg} \mathrm{~K} \mathrm{ha}^{-1}$ in total).

\subsection{2 | Yield, persistence and chemical composition}

Measurements were taken during 2012, 2014 and 2015, the first, third and fourth years after sowing. No measurements took place during 2013 as this year was deemed less relevant in terms of persistence. Total DMY at each harvest was determined by cutting a strip of $0.84 \mathrm{~m} \times 4 \mathrm{~m}$ within each plot with a front-bar mower (EuroSystems, Italy), leaving a sward stubble height of approximately $6 \mathrm{~cm}$. The samples were weighed and a subsample was taken for DM analysis. Samples were dried in a forced-draught oven at $70^{\circ} \mathrm{C}$ for $24 \mathrm{hr}$ and corrected for residual water content, by drying a subsample for $2 \mathrm{hr}$ at $105^{\circ} \mathrm{C}$ for DM determination. In 2015, for all harvests, a subsample was analysed for total nitrogen concentration (total $\mathrm{N}$, Kjeldahl, Eurofins-agro, The Netherlands), and based on this analysis the crude protein (CP) concentration and yield were calculated.

Additionally, for each harvest, a fresh subsample of at least $0.2 \mathrm{~kg}$ was manually separated into red clover, white clover, perennial ryegrass and weeds and herbs for obtaining the botanical composition. The separated red clover subsamples taken from the third cut in 2012, second cut in 2014 and first cut in 2015 were dried and analysed for ash concentration, $\mathrm{N}$-total (Kjeldahl) and digestible organic matter in the dry matter (DOMD) (Tilley \& Terry, 1963, Eurofins-agro, The Netherlands).

\subsection{3 | Clover morphology}

Before the first harvest in 2015 , plant density was determined by counting the number of red clover plants in a $1-\mathrm{m}^{2}$ quadrat within each plot. Additionally, morphological traits of the red clover cultivars were measured in three randomly chosen plants per plot, which were cut above root crown level. For each plant, ten normally developed medial leaflets (petiole not included) from the top $10-15 \mathrm{~cm}$ were cut for measuring the leaf area $\left(\mathrm{cm}^{2}\right)$ with ImageJ (Schneider, Rasband, \& Eliceiri, 2012), following the protocol of standardized measurement of plant functional traits (Pérez-Harguindeguy et al., 2013). These leaves were dried at $40^{\circ} \mathrm{C}$ for $72 \mathrm{hr}$ and corrected for residual water content, by drying a subsample for $2 \mathrm{hr}$ at $105^{\circ} \mathrm{C}$.
The specific leaf area (SLA, $\mathrm{cm}^{2} \mathrm{~g} \mathrm{DM}^{-1}$ ) was calculated as leaf area divided by leaf DM weight. For each plant, the number of stems was counted and the length of the longest stem was measured. The clover samples were divided into leaves and stems (petiole included) dried at $40^{\circ} \mathrm{C}$ for $72 \mathrm{hr}$ to determine shoot weight (g plant ${ }^{-1}$ ) and leaf/stem ratio $(\mathrm{g} / \mathrm{g})$.

\subsection{Pot experiment}

The four Mattenklee and four Ackerklee cultivars used in the field experiment and one perennial ryegrass (Lolium perenne L.) cultivar (cv. Mathilde) were sown in pots alone and in mixtures on 20 August 2014 in a glasshouse at Wageningen University, the Netherlands $\left(51^{\circ} 59^{\prime} 11^{\prime \prime} \mathrm{N}, 5^{\circ} 40^{\prime} 5^{\prime \prime} \mathrm{E}\right)$. The pot experiment was arranged in a randomized block design with four replicates and consisted of one grass monoculture, eight red clover monocultures and eight red cloverperennial ryegrass 50:50 mixtures per block. All the pots included four plants per pot at a distance of $5 \mathrm{~cm}$ in a square, and the mixture contained two plants of each species per pot.

The soil was collected from Nergena experimental farm at Wageningen University $\left(51^{\circ} 59^{\prime} 46^{\prime \prime} \mathrm{N}, 5^{\circ} 39^{\prime} 29^{\prime \prime} \mathrm{E}\right)$ and had a sandy texture. The soil was sieved through an aluminium mesh $(5 \mathrm{~mm})$ and mixed thoroughly. Each pot ( $1 \mathrm{~L}, 10 \mathrm{~cm}$ diameter) was filled with the same amount of approximately $1 \mathrm{~kg}$ soil. The soil $\mathrm{NH}_{4}{ }^{+}-\mathrm{N}$ and $\mathrm{NO}_{3}{ }^{-}-\mathrm{N}$ concentrations were 2.0 and $8.0 \mathrm{mg} / \mathrm{kg}^{-1}$ respectively. The temperature in the glasshouse was $20.9 / 16.5^{\circ} \mathrm{C}$ (day/night), and all the pots were arranged under a natural long-day light cycle condition. The pots were watered every day to keep the water-holding capacity constant at $60 \%$, maintained by regularly measuring the mass loss of each individual pot and addition of an equivalent weight of water. The pots were hand-weeded and received no fertilizers. The few plants affected by powdery mildew were sprayed with an organic fungicide (Microsulfo spuitzwavel; Bayer Garden, The Netherlands).

Eight weeks after sowing, all pots were harvested. Red clover and grass plant height were measured and clover leaf area (petiole included) per pot was measured by a leaf area scanner (LI-COR, USA). The clover plants were separated into leaves (petiole included) and stems and oven-dried at $70^{\circ} \mathrm{C}$ for $72 \mathrm{hr}$ for dry-matter (DM) determination.

\section{3 | Statistical analyses}

Data were subjected to analysis of variance (ANOVA) in Genstat (Genstat 18, VSB international). In separate analyses, the different yield and morphological response variables in the field and pot experiments were tested for a cultivar effect $(n=4)$, for a clovertype effect (Mattenklee vs. Ackerklee, $n=16$ ) and ploidy effect (diploid $[n=12]$ vs. tetraploid [ $n=20]$ ). Additionally, response variables from the pot experiment were tested for a mixture effect $(n=16)$. Data were checked for normality and log-transformed if required. Spearman's correlation coefficients were conducted in Genstat to determine the association between different morphological traits, nutritive value and persistence indicators. 


\section{3 | RESULTS}

\subsection{Field experiment}

\subsection{1 | Red clover content}

In 2012, the red clover content (\% of total herbage DMY) was similar for all cultivars with, on average, 58\% of the herbage yield being red clover (Figure 1). In 2014, the red clover cultivars differed in their proportional contribution to the herbage yield in the grass-clover mixtures and clover content ranged from $59 \%$ for Avanti (AK) to $81 \%$ for cv. Larus (MK) (significant cultivar effect at $p<.001$ ). There was also a significant difference between the Mattenklee and Ackerklee clover types $(p<.001)$, with Ackerklees representing on average $61 \%$ and Mattenklees $77 \%$ of the herbage DMY. In 2015, the clover content had decreased to $42 \%$ and $60 \%$ for Ackerklee and Mattenklee respectively (significant clover-type effect, $p<.001$ ). Clover content was highest for Larus (MK) (75\%) and lowest for Lemmon (AK) (37\%) (significant cultivar effect at $p<.001$ ). The decrease in red clover content from 2012 to 2015 was accompanied by an increase in the proportion of Lolium perenne from $31 \%$ to $47 \%$ and a decrease in the proportion of unsown species from $11 \%$ to 2\% (mainly Chenopodium album and Stellaria media, data not shown).

\subsection{2 | Red clover dry-matter yield}

In 2012, there was no significant effect of clover type on red clover DMY (Table 1), which was on average 6.7 t/ha. However in 2012 , there was a significant effect of cultivar $(p<.01)$ on red clover DMY, with the highest DMY for Maro (AK) (7.7 t/ha) and the lowest DMY for Milvus (MK; 5.4 t/ha). Moreover, the red clover DMY was significantly $(p<.01)$ higher for the tetraploid compared with the diploid cultivars. In 2014, the red clover DMY was on average $9.4 \mathrm{t} /$ ha and was significantly different between clover types, with DMY being 33\% higher for the Mattenklees compared with the Ackerklees $(p<.001)$. The clover DMY was also significantly different between red clover cultivars $(p<.001)$ being highest for Larus and Pavo (MK) (11 t/ha) and lowest for Avanti, Lemmon and Taifun (AK) (7.4, 7.9 and $7.9 \mathrm{t}$ /ha respectively). The mean red clover DMY yield in 2015 was $5.5 \mathrm{t} /$ ha and it was significantly $(p<.001)$ higher for the Mattenklees (6.7 t/ha) compared with the Ackerklees (4.4 t/ha). Clover DMY ranged from 3.7 t/ha for Lemmon (AK) to 8.4 to ha ${ }^{-1}$ for Larus (MK).

The cumulative red clover DMY across the three measurement years was significantly higher $(p<.001)$ for the Mattenklees (23.9 $\mathrm{t} \mathrm{DM} \mathrm{ha}^{-1}$ ) than for the Ackerklees (19.3 $\mathrm{t} \mathrm{DM} \mathrm{ha}^{-1}$, Table 1). Larus (MK) showed the highest and Lemmon (AK) the lowest cumulative red clover DMY

The persistence of red clover quantified as the yield index (relative red clover performance in 2015 compared with 2012) was significantly $(p<.001)$ higher for the Mattenklees compared with the Ackerklees, with $107 \%$ for Mattenklees and $67 \%$ for Ackerklees of the DMY production in 2012 (Table 1).

\subsection{3 | Total herbage dry-matter yield}

Total dry-matter yield followed a trend similar to the red clover drymatter yield, as described above; however, the differences between the clover types and cultivars were less pronounced (Table 1). For example, in 2015, total herbage DMY of the Mattenklees was only $8 \%$ higher than that of Ackerklees (compared with 54\% for red clover DMY). Mean total herbage DMY was 11.4, 13.5 and $10.7 \mathrm{t} /$ ha during 2012, 2014 and 2015 respectively.
2012

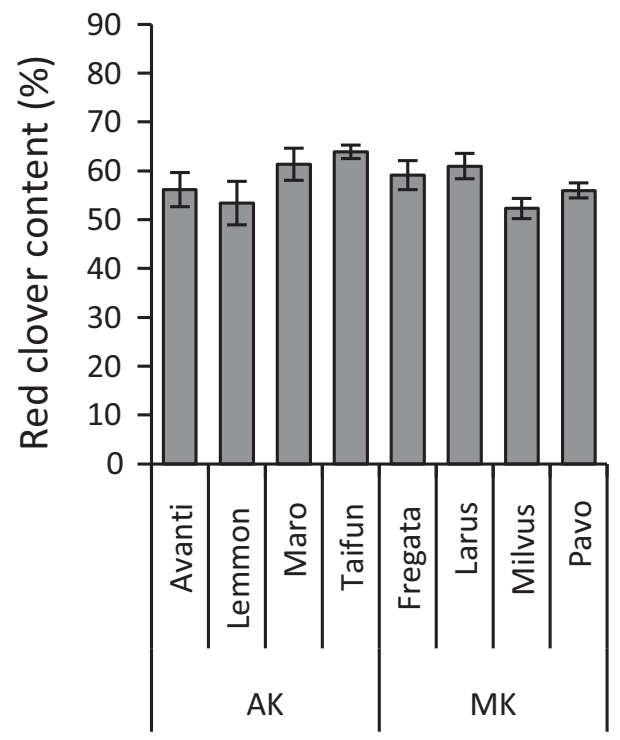

2014

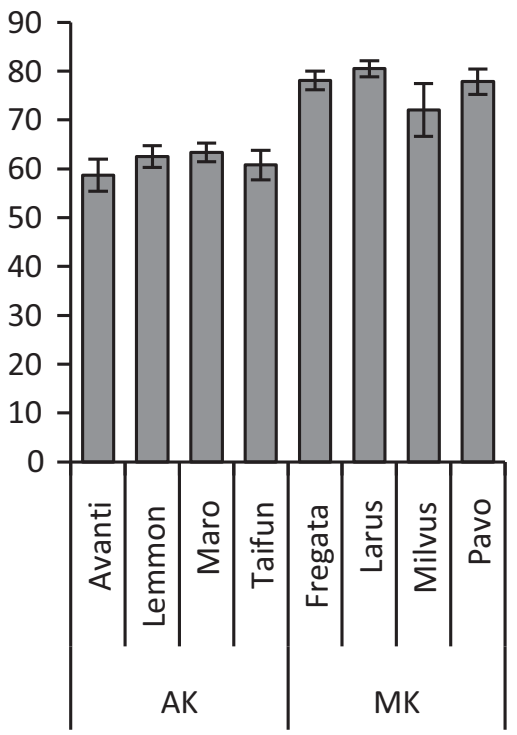

2015

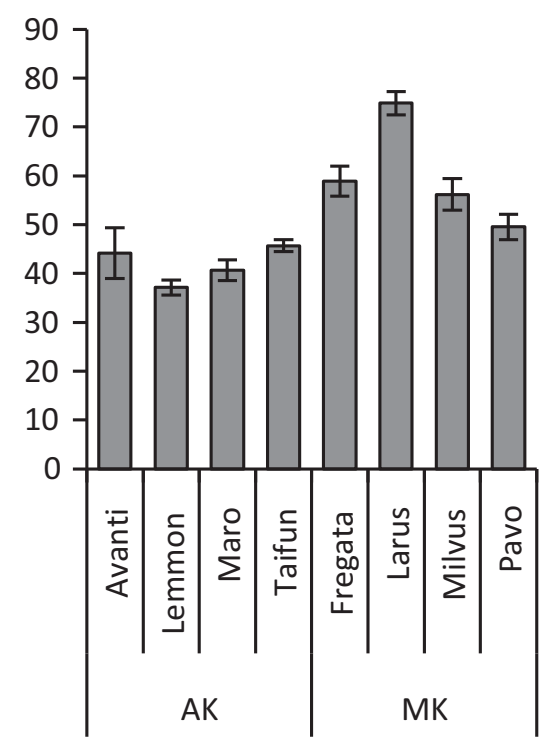

FIGURE 1 Mean red clover content (\% of total herbage dry-matter yield) of the four Ackerklee and the four Mattenklee cultivars in 2012 , 2014 and 2015. Error bars represent 1 SE $(n=4)$ 
TAB LE 1 Mean annual red clover dry-matter yield (DMY) and total herbage DMY of the four Ackerklees (AK) and four Mattenklees (MK) in 2012, 2014 and 2015 and the yield index (DMY 2015/DMY $2012 \times 100 \%$ )

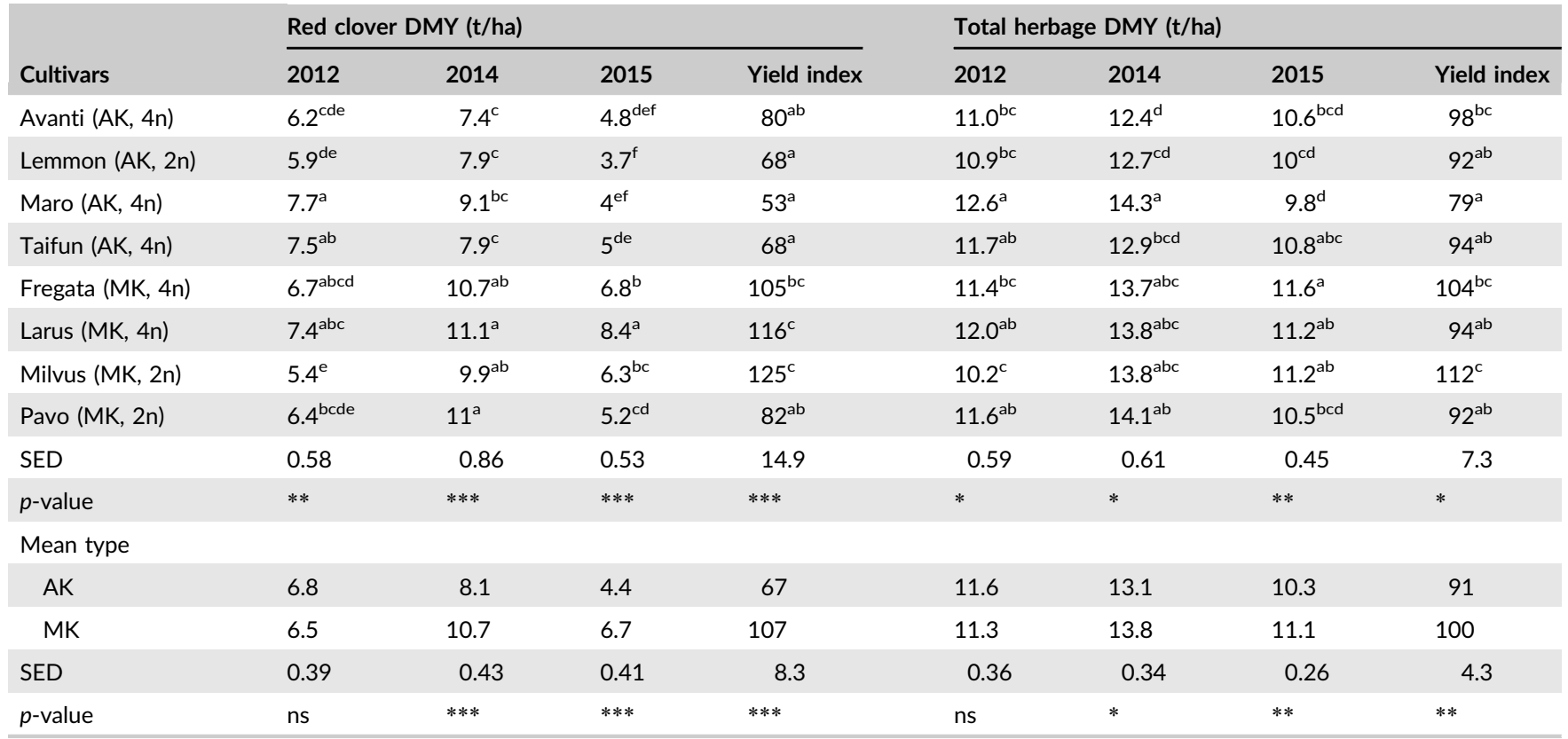

Cultivar data are means of four values. Values within columns followed by the same letters are not significantly different $(p>.05)$.

The total herbage DMY cumulative across the three measurement years was significantly $(p<.05)$, but only slightly higher for the Mattenklees (36.3 $\mathrm{t} \mathrm{DM} \mathrm{ha}^{-1}$ ) compared with the Ackerklees (35.0 $\mathrm{t} \mathrm{DM} \mathrm{ha}^{-1}$, Table 1). For the individual cultivars, Avanti and Lemmon (both $\mathrm{AK}$ ) had a significantly lower total herbage DMY compared with Maro (AK), Fregata (MK) and Larus (MK).

The yield index for total herbage DMY was significantly $(p<.001)$ higher for the Mattenklees compared with the Ackerklees, both in 2014 and in 2015 (Table 1), and in 2015 was on average 100\% for Mattenklee and 91\% for Ackerklee.

\subsection{4 | Crude protein concentration and yield}

In 2012-Harvest $3(\mathrm{H} 3)$ and $2014-\mathrm{H} 2$, there were no significant differences in red clover crude protein (CP) concentration between the cultivars (Table 2). In 2015- $\mathrm{H} 1$, there was a significant red clover cultivar $(p<.001)$ and type $(p<.001)$ effect on the red clover CP concentration, which was on average 223 for the Ackerklees and $188 \mathrm{~g} \mathrm{~kg}^{-1} \mathrm{DM}$ for the Mattenklees (Table 2). For all years, there was a significant $(p<.05)$ cultivar effect on the red clover CP yield (Table S3); however, the order of the cultivars differed between years. For example, Maro (AK, $4 n$ ) had the highest CP yield in 2012$\mathrm{H} 3$, but the lowest CP yield in 2015- H1. For the 2012-H3, there was no significant clover-type effect on clover CP yield, whereas for 2014- $\mathrm{H} 2$ and 2015-H1, clover CP yield was significantly $(p<.05)$ higher for the Mattenklees compared with Ackerklees (27\% higher during 2014 and 39\% higher during 2015).

For the total herbage CP concentration and yield (measured in 2015 only), there was a significant effect of cultivar and clover type $(p<.001$; Table 2). Herbage CP concentration was $9 \%$ higher and herbage CP yield was 18\% higher, for the Mattenklee cultivars (in particular Fregata and Larus) compared with the Ackerklee cultivars.

\subsection{5 | Red clover digestible organic matter concentration}

Red clover digestible organic matter concentration (DOMD) was on average $72 \%$ for the $2012-\mathrm{H} 3,73 \%$ for the $2014-\mathrm{H} 2$ and $77 \%$ for 2015-H1 (Table 3). During 2015, there was a significant cultivar $(p<.001)$ and type $(p<.001)$ effect on the red clover DOMD, which was on average $78.8 \%$ for the Ackerklees and $76.6 \%$ for the Mattenklees. Clover digestible organic matter yield ranged from $1,006 \mathrm{~kg} / \mathrm{ha}$ (Lemmon, 2015-H1) to 2,369 kg/ha (Maro, 2012-H1) (Table S3). Clover DOM yield was higher for Mattenklees than for Ackerklees, but only significantly so for the harvest at 2014- $22(p<.05)$.

\subsection{6 | Red clover morphology}

There was a significant $(p<.001)$ effect of cultivar on plant density, which was highest for Larus $\left(40\right.$ plants $\left./ \mathrm{m}^{2}\right)$ and lowest for Lemmon (12 plants $/ \mathrm{m}^{2}$ ) (Table 4). Plant density was significantly $(p<.001)$ higher for the Mattenklee compared to the Ackerklee type, with 32 and 21 plants $/ \mathrm{m}^{2}$ respectively. Shoot weight was also significantly $(p<.05)$ higher for the Mattenklees $(12.7 \mathrm{~g} / \mathrm{plant})$ compared with the Ackerklees $(9.5 \mathrm{~g} /$ plant). The specific leaf area was on average $231 \mathrm{~cm}^{2} \mathrm{~g} \mathrm{DM}^{-1}$ and there were no significant effects of cultivar, type or ploidy. Mean stem length $(\mathrm{cm})$ ranged from $34 \mathrm{~cm}$ for Lemmon (AK) to $49 \mathrm{~cm}$ for Larus (MK). The Mattenklees had a significantly $(p<.001)$ longer stem than the Ackerklees. The leaf/stem ratio ranged from $0.45 \mathrm{~g} / \mathrm{g}$ for Milvus (MK) to $0.62 \mathrm{~g} / \mathrm{g}$ for Taifun 
TAB LE 2 Red clover crude protein (CP) content (g kg-1 DM) of the four Ackerklees (AK) and four Mattenklees (MK) during the third harvest $(H 3)$ in 2012, the second harvest $(H 2)$ in 2014 and the first harvest $(\mathrm{H} 1)$ in 2015 and total average herbage CP concentration and cumulative herbage CP yield during 2015

\begin{tabular}{|c|c|c|c|c|c|}
\hline \multirow[b]{2}{*}{ Cultivars } & \multicolumn{3}{|c|}{$\begin{array}{l}\text { Red clover CP } \\
\text { concentration } \\
\left(\mathrm{g} \mathrm{kg}^{-1} \mathrm{DM}\right)\end{array}$} & \multirow{2}{*}{$\begin{array}{l}\text { Herbage CP } \\
\text { concentration } \\
\left(\mathrm{g} \mathrm{kg}^{-1} \mathrm{DM}\right) \\
2015\end{array}$} & \multirow{2}{*}{$\begin{array}{l}\text { Herbage } \\
\text { CP yield } \\
\text { (kg/ha) }\end{array}$} \\
\hline & $\begin{array}{l}2012- \\
\text { H3 }\end{array}$ & $\begin{array}{l}2014- \\
\text { H2 }\end{array}$ & $\begin{array}{l}2015- \\
\text { H1 }\end{array}$ & & \\
\hline Avanti (AK, 4n) & 209 & 194 & $215^{\mathrm{b}}$ & $169^{\mathrm{bcd}}$ & $1,777^{\mathrm{bc}}$ \\
\hline Lemmon (AK, 2n) & 211 & 202 & $215^{b}$ & $151^{\mathrm{e}}$ & $1,510^{d}$ \\
\hline Maro (AK, 4n) & 210 & 209 & $221^{\mathrm{b}}$ & $163^{\mathrm{cd}}$ & $1,602^{\mathrm{cd}}$ \\
\hline Taifun (AK, 4n) & 196 & 200 & $242^{\mathrm{a}}$ & $162^{\mathrm{de}}$ & $1,760^{\mathrm{bc}}$ \\
\hline Fregata (MK, 4n) & 193 & 199 & $182^{c}$ & $176^{\mathrm{ab}}$ & $2,041^{a}$ \\
\hline Larus (MK, 4n) & 208 & 198 & $190^{c}$ & $182^{\mathrm{a}}$ & $2,034^{a}$ \\
\hline Milvus (MK, 2n) & 201 & 203 & $189^{c}$ & $173^{a b c}$ & $1,945^{\mathrm{ab}}$ \\
\hline Pavo (MK, 2n) & 207 & 196 & $190^{c}$ & $171^{\mathrm{bcd}}$ & $1,800^{b c}$ \\
\hline SED & 8.9 & 6.2 & 55.4 & 4.8 & 103.8 \\
\hline$p$-value & ns & ns & $* * *$ & $* * *$ & $* * *$ \\
\hline \multicolumn{6}{|l|}{ Type } \\
\hline AK & 206 & 201 & 223 & 161 & 1,654 \\
\hline MK & 202 & 199 & 188 & 175 & 1,955 \\
\hline SED & 4.5 & 3.1 & 40.4 & 3.0 & 61.4 \\
\hline$p$-value & ns & ns & $* * *$ & $* * *$ & $* * *$ \\
\hline
\end{tabular}

Cultivar data are means of four values. Values within columns followed by the same letters are not significantly different $(p>.05)$.

TABLE 3 Red clover digestible organic matter concentration in the dry matter (DOMD, $\mathrm{g} \mathrm{kg}^{-1} \mathrm{DM}$ ) of the four Ackerklees (AK) and four Mattenklees (MK) during the third harvest $(\mathrm{H} 3)$ in 2012, the second harvest $(\mathrm{H} 2)$ in 2014 and the first harvest $(\mathrm{H} 1)$ in 2015

\begin{tabular}{|c|c|c|c|}
\hline \multirow[b]{2}{*}{ Cultivars } & \multicolumn{3}{|c|}{ Red clover DOMD (g kg-1 DM) } \\
\hline & 2012-H3 & 2014-H2 & 2015-H1 \\
\hline Avanti (AK, 4n) & 721 & 732 & $787^{\mathrm{ab}}$ \\
\hline Lemmon (AK, 2n) & 726 & 737 & $785^{\mathrm{ab}}$ \\
\hline Maro (AK, 4n) & 723 & 743 & $791^{a}$ \\
\hline Taifun (AK, 4n) & 714 & 724 & $791^{a}$ \\
\hline Fregata (MK, 4n) & 704 & 727 & $753^{d}$ \\
\hline Larus (MK, 4n) & 714 & 724 & $773^{\mathrm{bc}}$ \\
\hline Milvus (MK, 2n) & 704 & 737 & $763^{\text {cd }}$ \\
\hline Pavo (MK, 2n) & 724 & 736 & $773^{\mathrm{bc}}$ \\
\hline SED & 9.6 & 10.4 & 8.3 \\
\hline$p$-value & ns & ns & $* * *$ \\
\hline \multicolumn{4}{|l|}{ Type } \\
\hline AK & 721 & 733 & $788^{a}$ \\
\hline MK & 712 & 731 & $766^{\mathrm{b}}$ \\
\hline SED & 5.0 & 5.1 & 4.4 \\
\hline$p$-value & .07 & ns & $* * *$ \\
\hline
\end{tabular}

Cultivar data are means of four values. Values within columns followed by the same letters are not significantly different $(p>.05)$.
TABLE 4 Morphological traits of the four Ackerklee (AK) and four Mattenklee (MK) red clover cultivars measured in the first cut during 2015

\begin{tabular}{|c|c|c|c|c|c|}
\hline Cultivars & $\begin{array}{l}\text { Plant } \\
\text { density } \\
\left(\# \mathrm{~m}^{-2}\right)\end{array}$ & $\begin{array}{l}\text { Shoot } \\
\text { weight } \\
\text { (g/plant) }\end{array}$ & $\begin{array}{l}\text { SLA } \\
\left(\mathrm{cm}^{2} \mathrm{~g}\right. \\
\left.\mathrm{DM}^{-1}\right)\end{array}$ & $\begin{array}{l}\text { Stem } \\
\text { length } \\
(\mathrm{cm})\end{array}$ & $\begin{array}{l}\text { Leaf/stem } \\
\text { ratio }(\mathrm{g} / \mathrm{g})\end{array}$ \\
\hline Avanti (AK, 4n) & $26.7^{\mathrm{cd}}$ & 10.0 & 231 & $38.9^{\mathrm{cd}}$ & $0.60^{a b}$ \\
\hline Lemmon (AK, 2n) & $12.3^{f}$ & 9.0 & 248 & $33.8^{d}$ & $0.49^{c d}$ \\
\hline Maro $(\mathrm{AK}, 4 \mathrm{n})$ & $21.8^{\mathrm{e}}$ & 8.6 & 239 & $41.7^{\mathrm{bc}}$ & $0.55^{a b c}$ \\
\hline Taifun (AK, 4n) & $23.4^{\mathrm{de}}$ & 10.3 & 222 & $39.8^{c}$ & $0.62^{\mathrm{a}}$ \\
\hline Fregata (MK, 4n) & $31.6^{\mathrm{b}}$ & 10.6 & 221 & $47.9^{a}$ & $0.55^{\mathrm{abc}}$ \\
\hline Larus (MK, 4n) & $40.3^{a}$ & 13.4 & 222 & $48.9^{a}$ & $0.50^{\text {cd }}$ \\
\hline Milvus (MK, 2n) & $32.5^{\mathrm{b}}$ & 13.7 & 237 & $47.5^{\mathrm{ab}}$ & $0.45^{d}$ \\
\hline Pavo (MK, 2n) & $25.5^{\mathrm{cd}}$ & 13.2 & 233 & $45.9^{\mathrm{ab}}$ & $0.52^{\mathrm{bcd}}$ \\
\hline SED & 1.67 & 2.71 & 16.4 & 2.88 & 0.037 \\
\hline$p$-value & $* * *$ & ns & ns & $* * *$ & $* *$ \\
\hline \multicolumn{6}{|l|}{ Type } \\
\hline AK & 21.1 & 9.5 & 235 & 38.6 & 0.56 \\
\hline MK & 32.5 & 12.7 & 228 & 47.6 & 0.51 \\
\hline SED & 2.17 & 1.26 & 7.9 & 1.52 & 0.023 \\
\hline$p$-value & $* * *$ & $*$ & ns & $* * *$ & .06 \\
\hline
\end{tabular}

Cultivar data are means of four values. Values within columns followed by the same letters are not significantly different $(p>.05)$.

(AK) (significant cultivar effect at $p<.01$ ). The leaf/stem ratio tended to be higher for the Ackerklees and was significantly $(p<.01)$ higher for tetraploid compared to diploid cultivars.

\section{2 | Pot experiment}

\subsubsection{Red clover and grass yield}

There was a significant cultivar effect $(p<.001)$ and clover-type effect $(p<.001)$ on the red clover yield in the pot experiment, and monoculture yields ranged from $4.6 \mathrm{~g} /$ pot for Avanti (AK) to $6.0 \mathrm{~g} /$ pot for Fregata (MK) (Figure 2). Red clover yield was significantly $(p<.001)$ lower in mixtures $(3.9 \mathrm{~g} / \mathrm{pot})$ than in monocultures $(5.4 \mathrm{~g} /$ pot). However, the relative yield ( $\mathrm{RY}=\mathrm{mix} / \mathrm{mono}$ ) which takes into account planted red clover density in the mixture relative to the monoculture was on average 0.7 (which was higher than 0.5 as expected based on sown proportion). This indicates that the biomass yield per red clover plant was significantly higher in mixtures compared with monocultures (Figure 3a). There was no significant interaction between cultivar (or clover type) and mixture, indicating that all cultivars were equally affected by growing in a mixture with L. perenne.

The grass yield was on average 0.5 and $0.2 \mathrm{~g} /$ pot for monocultures and mixtures respectively. The grass RY was on average 0.5 (indicating that the yield per grass plant was not affected by growing in mixture with red clover) and was not significantly affected by red clover cultivar or type. 


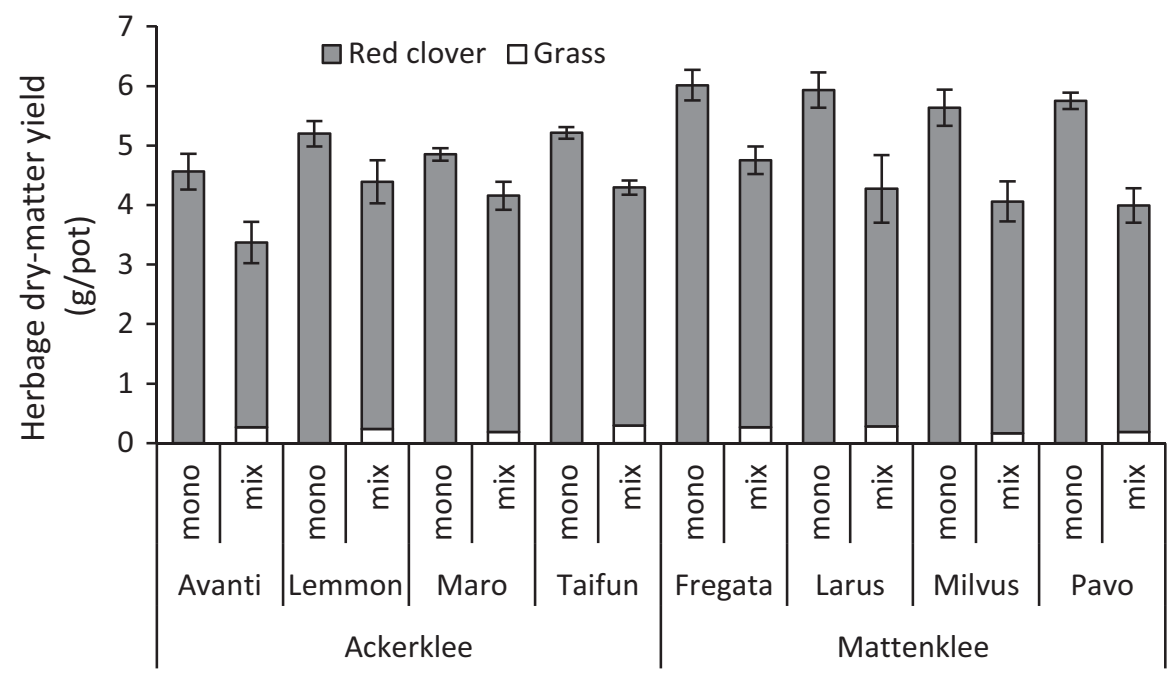

FIGURE 2 Grass and red clover drymatter yield of the four Ackerklee and the four Mattenklee cultivars grown in monoculture or mixture in the pot experiment

\subsection{2 | Red clover morphology}

Red clover plant height, SLA and leaf/stem ratio were all significantly $(p<.001)$ affected by red clover cultivar and type (Figure 3b-d). Red clover plant height ranged from $20.4 \mathrm{~cm}$ for Lemmon (AK) to $27.2 \mathrm{~cm}$ for Fregata (MK), the SLA ranged from $168 \mathrm{~cm}^{2} / \mathrm{g}$ DW for Fregata (MK) to $208 \mathrm{~cm}^{2} / \mathrm{g} \mathrm{DW}$ for Avanti (AK), and the leaf/stem ratio was lowest for Fregata and Milvus (MK, $1.0 \mathrm{~g} / \mathrm{g}$ ) and highest for the Ackerklees $(1.2 \mathrm{~g} / \mathrm{g})$. For red clovers grown in mixture compared to monoculture, the plant height was significantly $(p<.001)$ higher, whereas the leaf/stem ratio was significantly $(p<.001)$ lower (Figure 3$)$.

\section{3 | Correlations}

\subsection{1 | Correlation between pot and field results}

There was a good correlation $(r=.77 ; p<.05)$ between the plant height (or stem length) measurements in the pot (both mono and mixture) and the field experiment (Table 5). All the other traits (shoot weight, SLA and leaf/stem ratio) showed a positive (but nonsignificant) correlation between pot and field measurements (with the exception of mixture shoot biomass). In general, the pot monoculture measurements showed stronger correlations with the field experiment compared to the mixture measurements.

\subsection{2 | Competition}

In the field experiment, there was a strong negative correlation $(r=-.84, p<.001)$ between the red clover dry-matter yield and the grass dry-matter yield during all 3 years. In contrast, the total herbage dry-matter yield was positively correlated with the red clover dry-matter yield $(r=.93, p<.001)$. In the pot experiment, there was no correlation between clover and grass performance.

\subsection{3 | Persistence, nutritive value and morphology}

There was a strong and highly significant $(p<.001)$ correlation in the field experiment between the three red clover persistence indicators in 2015: the red clover DMY during the first harvest in 2015, the cumulative red clover DMY over 2015 and the red clover yield index in 2015 (Table 6).

All three persistence indicators were significantly and positively correlated with the red clover plant density, stem length and red clover shoot weight (except red clover DMY_H1) (Table 6). Also, the number of stems per plant was positively correlated with the red clover yield index. In 2015-H1, red clover persistence (red clover DMY$\mathrm{H} 1$ and red clover yield index) was negatively correlated with red clover CP and DOMD concentration (Table 6). However, during 2012$\mathrm{H} 3$ and $2014-\mathrm{H} 2$, there were no significant correlations between clover DMY and clover CP or DOMD concentration (data not shown).

The difference in nutritive value in $2015-\mathrm{H} 1$ could be linked to clover morphology as there was a significant negative correlation between the stem length and clover $\mathrm{CP}$ and DOMD, whereas the leaf/stem ratio was positively correlated with the CP and DOMD.

Even though the clover CP concentration in 2015- H1 showed a (non-significant) negative correlation with clover DMY (Figure 4a), the red clover DMY was positively correlated with the red clover CP yield $\left(r=.97^{* * *}\right)$ (Figure $\left.4 \mathrm{~b}\right)$. Additionally, the total herbage CP concentration was positively correlated with the proportion of red clover in the herbage biomass ( $r=.87^{* *}$, Figure 4c).

\section{4 | DISCUSSION}

\subsection{Higher persistence of Ackerklee red clover cultivars}

There was no significant difference in red clover DMY between the Ackerklees and the Mattenklees during the first year after sowing (2012). However, the red clover DMY of the Mattenklees in comparison with the Ackerklees was on average 33\% higher in the third year (2014) and 54\% higher in the fourth year (2015). This was in line with our expectations and indicates that breeding effort into more persistent red clover cultivars (Lehmann \& Briner, 1998) is also effective under the local conditions in the Netherlands. Cumulatively across the 
(a) Shoot weight

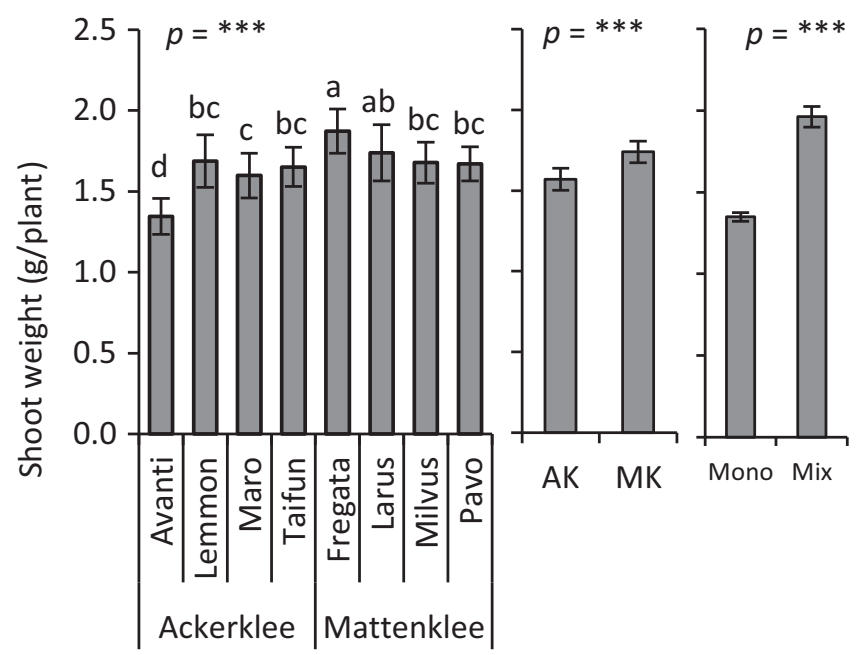

Cultivar

(c) SLA

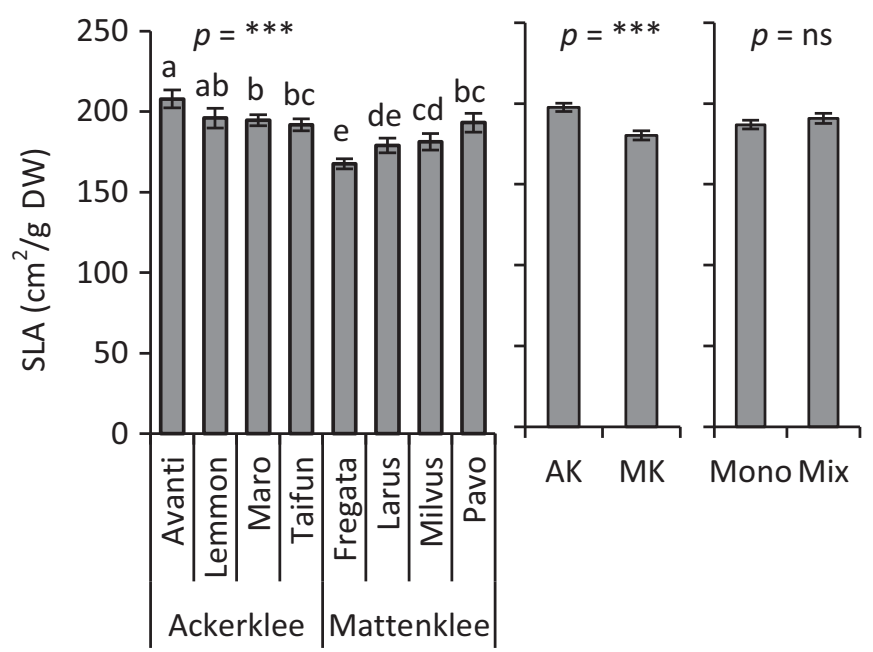

\section{(b) Plant height}

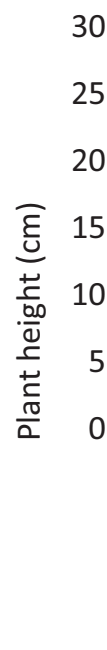

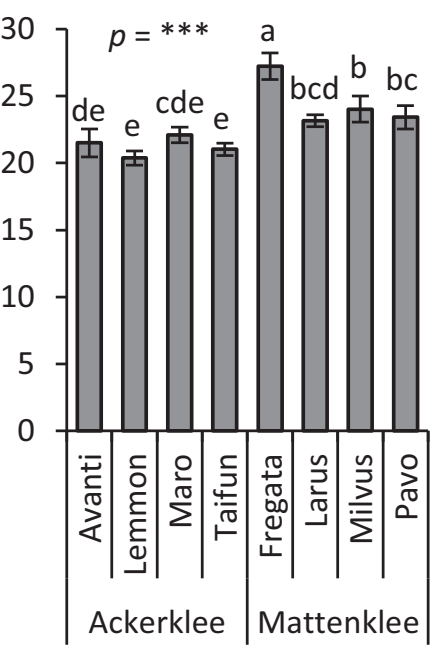

Cultivar

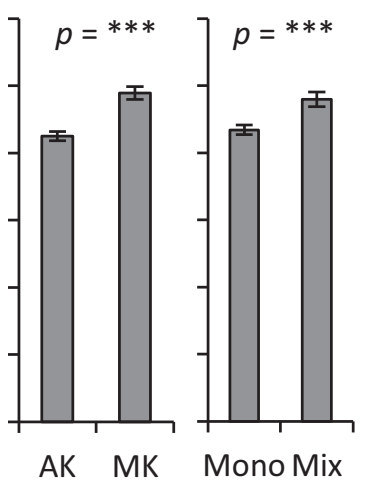

AK MK Mono Mix

\section{(d) Leaf/stem ratio}

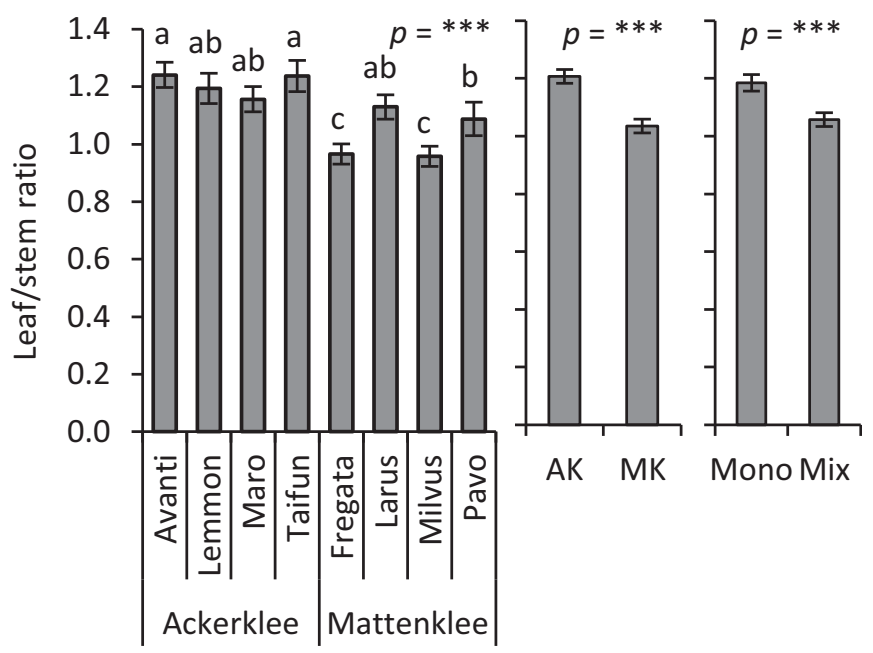

FIGURE 3 The effect of red clover cultivar, red clover type (Ackerklee vs. Mattenklee) and mixture (monoculture vs. mixture) on (a) the shoot weight, (b) plant height, (c) SLA and (d) leaf/stem ratio of the eight red clover cultivars grown in the pot experiment. Error bars represent the standard error ( $n=4$ for cultivars, $n=16$ for clover type and mixture means). Bars with the same letters are not significantly different ( $p>.05$ )

TABLE 5 Coefficients of correlation of plant morphological traits measured in the pot experiment (in monocultures and mixtures) and in the field experiment

\begin{tabular}{|c|c|c|c|c|c|c|}
\hline & \multicolumn{2}{|c|}{$\begin{array}{l}\text { Pot: Mono } \\
\text { vs. mix }\end{array}$} & \multicolumn{2}{|c|}{$\begin{array}{l}\text { Pot-mono } \\
\text { vs. field }\end{array}$} & \multicolumn{2}{|c|}{$\begin{array}{l}\text { Pot-mix vs. } \\
\text { field }\end{array}$} \\
\hline & $r$ & $p$ & $r$ & $p$ & $r$ & $p$ \\
\hline Shoot weight & .65 & .08 & .68 & .06 & -.04 & ns \\
\hline SLA & .78 & $*$ & .41 & ns & .46 & ns \\
\hline Plant height & .87 & $* *$ & .77 & $*$ & .78 & $*$ \\
\hline Leaf/stem ratio & .86 & $* *$ & .68 & .07 & .44 & ns \\
\hline
\end{tabular}

Significant correlations are indicated by $* p<.05 ; * * p<.01 ; * * p<.001$.

three measurement years (2012, 2014 and 2015), Larus and Fregata (both MK) performed best with the highest red clover DMY, whereas Avanti and Lemmon (both $\mathrm{AK}$ ) had the lowest clover DMY.
The higher red clover DMY of the Mattenklees was the result of a greater number of remaining plants per $\mathrm{m}^{2}$ combined with a higher shoot DMY (Tables 4 and 6). After 4 years, both the survival rate of the plants and the production per plant were higher for the Mattenklees than for the Ackerklees. Persistence is often measured as the number of surviving plants (Choo, 1984); however, persistence may also be defined as the ability of plants to produce a satisfactory forage yield in the third or fourth growing seasons (Taylor \& Quesenberry, 1996). Therefore, good persistence should be a combination of plant survival and plant vigour and, in practice, these traits are often correlated. In the current experiment, Larus (MK) had both the greatest number of surviving plants and the highest shoot weight, whereas Lemmon (AK) had the lowest plant density and the second-lowest shoot weight (Table 4). 
TABLE 6 Coefficients of correlation of plant morphology traits measured during H1 in 2015 (plant density, shoot weight, leaf area, leaf/stem ratio, number of stems per plant, SLA and stem length) with red clover performance (red clover dry-matter yield during H1 and total 2015 and clover yield index) and with clover nutritive value (crude protein (CP) concentration and digestible organic matter (DOMD) concentration)

\begin{tabular}{|c|c|c|c|c|c|}
\hline & \multicolumn{3}{|l|}{ Clover performance } & \multicolumn{2}{|c|}{ Clover nutritive value } \\
\hline Clover DMY (H1) & - & $0.95 * * *$ & $0.88 * *$ & -0.60 & -0.58 \\
\hline Plant density & $0.93^{* * *}$ & $0.93 * * *$ & $0.81 *$ & -0.60 & -0.58 \\
\hline Shoot weight & 0.68 & $0.72 *$ & $0.81 *$ & -0.65 & -0.57 \\
\hline Leaf/stem ratio & -0.26 & -0.28 & -0.56 & 0.63 & 0.49 \\
\hline SLA & -0.60 & -0.68 & -0.36 & 0.12 & 0.29 \\
\hline Stem length & $0.71 *$ & $0.85 * *$ & $0.76 *$ & $-0.75^{*}$ & $-0.75 *$ \\
\hline Number of stems & 0.63 & 0.63 & $0.83 * *$ & -0.54 & -0.62 \\
\hline
\end{tabular}

Significant correlations are indicated in boldface: $* p<.05 ; * *<.01 ; * * p<.001$.
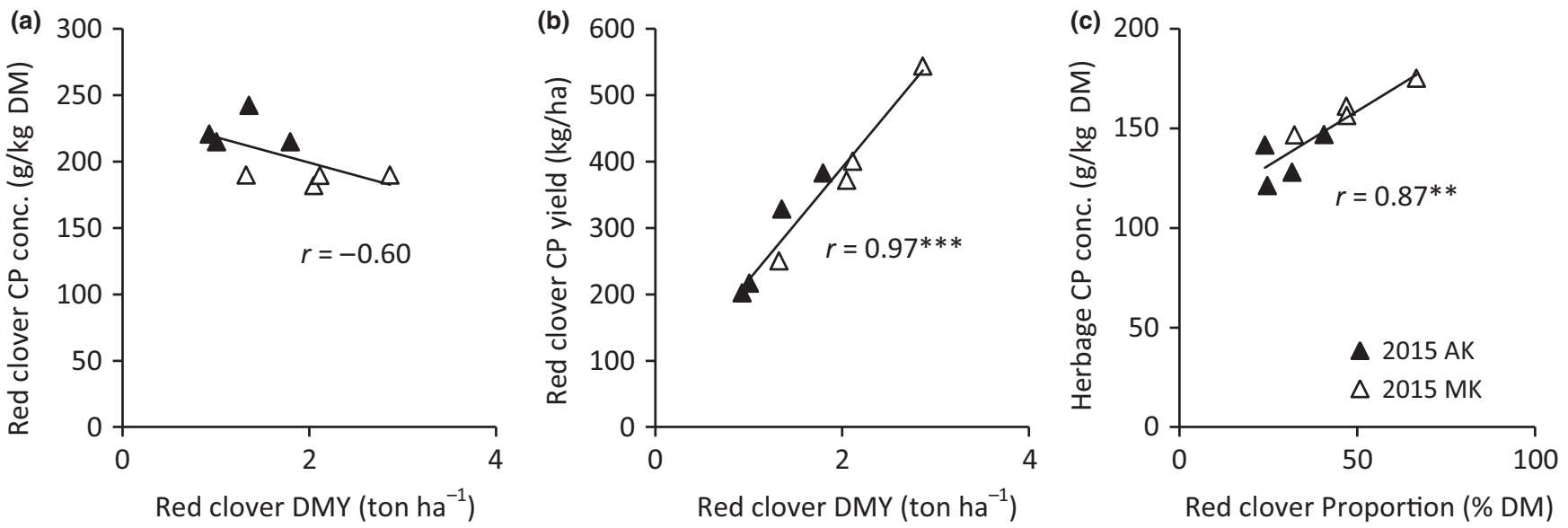

FIGURE 4 Correlation of red clover dry-matter yield (DMY) with (a) red clover crude protein (CP) concentration and (b) red clover CP yield, and (c) the correlation of total herbage CP content with the proportion of red clover in total herbage biomass for the four Ackerklee (closed symbols) and Mattenklee (open symbols) cultivars during the first cut in 2015

The red clover yield showed a marked decline in 2015 compared with 2014 for both types of red clover, but the decline was less pronounced for Mattenklee compared with Ackerklee (37\% and $46 \%$ respectively). A progressive decline in annual DM production as the sward ages is typical of clover swards, even in the absence of pests and diseases, due to natural decline in plant populations (Frame et al., 1998); however, we cannot exclude a role for stochastic yearto-year variation.

\section{2 | Red clover persistence and competitiveness related to plant morphological traits}

The differences in red clover DMY were broadly reflected in the total DMY; however, the differences in total herbage DMY between cultivars and clover types were much less pronounced (only 6\% and $8 \%$ respectively). This was related to the increasing proportion of red clover in the total DMY of the Mattenklees. Due to the high competitiveness of these cultivars, some of the increase in red clover yield was offset by a reduction in the yield of the perennial ryegrass component of the sward. Mixtures of red clover and perennial ryegrass usually show higher DMY compared with the average yields of both species in monoculture, because of facilitation and complementarity effects (Nyfeler et al., 2011). Red clover acquires a large proportion of its $\mathrm{N}$ through symbiotic $\mathrm{N}_{2}$ fixation. Perennial ryegrass can benefit from this in two ways: (i) directly through recycling of symbiotically fixed $\mathrm{N}$ and (ii) indirectly through increased $\mathrm{N}$ availability in the soil as a result of the lower soil $\mathrm{N}$ uptake of clover plants compared with perennial ryegrass plants (Nyfeler et al., 2011). In the pot experiment, no benefit was observed for growing perennial ryegrass in mixture with red clover. This is likely due to the short duration of the pot experiment which was too short to enable a measurable increase in soil $\mathrm{N}$ by the red clover via $\mathrm{N}$-fixation and root turnover.

The differences in competitiveness of the clover cultivars compared to the grass may be related to the higher plant height (stem length) of Mattenklee compared to Ackerklee (Table 4), which results 
in advantage for light competition (Den Hollander, Bastiaans, \& Kropff, 2007). Also, Herrmann et al. (2008) reported that persistence in the field was positively correlated with stem length. However, in a glasshouse study with 85 accessions of red clover from the NPGSUSDA core collection, Dias, Julier, Sampoux, Barre, and Dall'Agnol (2008) found that persistence was negatively correlated with plant height. The differences between these studies suggest that plant height or stem length may be a more appropriate indicator of persistence when plants are grown in mixture rather than in monoculture; i.e., it will give a competitive advantage in interspecific competition, but not in intraspecific competition. This highlights the need of cultivar assessments in both monocultures and agronomic mixtures, using glasshouse studies and long-term field experiments, and tests of their consistency (Lehmann \& Briner, 1998).

Interestingly, plant heights measured in both monocultures and mixtures in the short-duration pot experiment (Figure 3) showed a strong correlation with the stem length measured in the field experiment. The apparent robustness of this measurement strengthens the potential of this plant trait for use in plant selection and breeding.

Next to the effects of competition, persistence can be related to plant diseases. The difference in red clover plant density in 2015 between the cultivars indicates that there was a difference in the number of plants that failed to survive or difference in the establishment of new seedlings. This may be the result of a difference in the susceptibility to disease. For example, it is known that red clover varieties can differ markedly in resistance to southern anthracnose (Colletotrichum trifolii) (Jacob et al., 2015), and Mattenklee cultivars generally show a higher resistance (Lehmann \& Briner, 1998). However, we have no observations confirming that the difference in persistence between cultivars in the current study was (in part) caused by this differential susceptibility to $C$. trifolii.

\subsection{Potential trade-off between persistence and nutritive value in red clover biomass, but not in total herbage biomass}

During $2012-\mathrm{H} 3$ and $2014-\mathrm{H} 2$, there were no significant differences in $\mathrm{CP}$ concentration and DOMD between the different cultivars. However, in 2015-H1, CP concentration and DOMD were significantly lower for the MK compared with the AK cultivars (Tables 2 and 3 ), indicating a trade-off between DM yield and nutritive quality, as highlighted by the trend of a negative correlation between $\mathrm{CP}$ and DOMD and red clover DMY (Table 6). These lower CP and DOMD concentrations were negatively correlated with the stem length and positively with leaf/stem ratio (Table 6). This is in line with results in the literature indicating that red clover leaves have a higher digestibility and $\mathrm{CP}$ concentration than the stems (Kleen et al., 2011; Rinne \& Nykanen, 2000; Tucak \& Popovic, 2013; Wilman \& Altimimi, 1984).

However, the decrease in $\mathrm{CP}$ concentration of the red clover herbage had no negative impact on the $\mathrm{CP}$ concentration and yield of the total herbage. First, the decrease in clover $\mathrm{CP}$ concentration did not result in a lower CP yield; in fact, the opposite was true. As a result, there was a positive correlation between red clover DMY and red clover CP yield (Figure 4b). Second, in the mixtures, a higher red clover DMY was achieved partly at the cost of the grass yield, resulting in an increased proportion of red clover in the total herbage dry matter. Because the $\mathrm{CP}$ concentration of red clover is higher than that of perennial ryegrass (King, McEniry, Richardson, \& O'Kiely, 2012), the CP concentration of the total herbage increased. Therefore, the clover CP concentration was not correlated (or even negatively related) with the total herbage CP concentration. Instead, the proportion of red clover in the total herbage biomass was a much better predictor of the total herbage $\mathrm{CP}$ concentration.

Even though there was some evidence of slightly lower DOMD values for the Mattenklees compared with the Ackerklees during 2015-H1 (766 and $788 \mathrm{~g} / \mathrm{kg}$, respectively, Table 3), the digestible organic matter yield was actually higher for Mattenklee than for Ackerklee. The difference between the cultivar with the highest and the lowest DOMD was $5 \%$. We have no measurements of the total herbage DOMD. Literature shows that the digestibility of red clover may be slightly lower than (Frame et al., 1972), or comparable (King et al., 2012; Laidlaw \& McBratney, 1980; Moharrery, Hvelplund, \& Weisbjerg, 2009) to, perennial ryegrass, depending on season, management and cultivar.

We obtained a significant effect of clover type on nutritive value only in 2015. This may have been related to the diverging development of the two clover types in relation to their differences in persistence. Additionally, in 2015, red clover nutritive value was determined in the first cut, whereas in 2012 and 2014, it was determined in the third and fourth cut, respectively, which may also have had an effect on the differentiation between cultivars. However, the latter is unlikely as research by Frame et al. (1972) showed that differences in digestibility were actually smaller (and non-significant) in the first harvest in comparison with the subsequent harvests.

\section{5 | CONCLUSIONS}

In line with our hypothesis, the Mattenklees showed a higher production and a higher clover content in the third and fourth year of production compared with the Ackerklees, indicating that these cultivars are suitable for inclusion in a multiple ( $>4$ year) grass-clover ley. Even though in the first harvest of the fourth measurement year, the Mattenklee cultivars had a slightly lower digestibility and lower protein content in the red clover herbage, the protein content, digestible dry-matter yield and protein yield in the total herbage biomass were higher for Mattenklee cultivars.

Both persistence and nutritive value of the different red clover cultivars were closely correlated with plant morphological traits, particularly stem length and leaf/stem ratio. For plant height (or stem length), there was close correlation between the results from the pot experiment and the field experiment, indicating that this may be an important parameter for breeding. 


\section{ACKNOWLEDGMENTS}

This research was funded by ZuivelNL (Dutch Dairy Board) and Stuurgroep Landbouw Innovatie Noord-Brabant. Seeds of red clover cultivars were supplied by Barenbrug, Limagrain, DVS, DSP and Innoseeds. Marco van Liere is acknowledged for providing the land for the field trial. The authors would like to thank Riekje Bruinenberg and Hans Dullaert for sample sorting and Rene Groenen for assistance with grass sampling. We thank Janna Barel for help with the pot experiment. GBDD acknowledges FP7-IEF EU Marie-Skłodowska Curie for financial support.

\section{REFERENCES}

Annicchiarico, P., \& Pagnotta, M. A. (2012). Agronomic value and adaptation across climatically contrasting environments of Italian red clover landraces and natural populations. Grass and Forage Science, 67, 597-605.

Boller B. (2000) History and development of the Swiss "Mattenklee", a persistent form of cultivated red clover. Vierteljahresschr Nat Forsch Ges Zürich, 145, 143-151.

Boller, B., Schubiger, F. X., \& Kölliker, R. (2010). Red clover. In B. Boller, U. K. Posselt, \& F. Veronesi (Eds.), Fodder crops and amenity grasses (pp. 439-455). New York, NY: Springer.

Choo, T. M. (1984). Association between growth habit and persistence in red clover. Euphytica, 33, 177-185.

Christensen, M. J., Koga, H., Tsukiboshi, T., \& Uematsu, T. (1994). Possible causes of poor persistence of red clover [Trifolium pratense] stands in Japan. Bulletin of the National Grassland Research Institute, 49, 43-50.

Coulman, B. E., \& Lambert, M. (1995). Selection for resistance to root rot caused by Fusarium spp. in red clover (Trifolium pratense L.). Canadian Journal of Plant Science, 75, 141-146.

Delclos, B., Mousset-Déclas, C., \& Raynal, G. (1997). A simple method for the evaluation of red clover (Trifolium pratense L.) resistance to Sclerotinia trifoliorum. Euphytica, 93, 173-179.

Den Hollander, N. G., Bastiaans, L., \& Kropff, M. J. (2007). Clover as a cover crop for weed suppression in an intercropping design: II. Competitive ability of several clover species. European Journal of Agronomy, 26, 104-112.

Dias, P. M. B., Julier, B., Sampoux, J.-P., Barre, P., \& Dall'Agnol, M (2008). Genetic diversity in red clover (Trifolium pratense L.) revealed by morphological and microsatellite (SSR) markers. Euphytica, 160, 189-205.

Ford, J. L., \& Barrett, B. A. (2011). Improving red clover persistence under grazing. In Proceedings of the NZ Grassland Association, (Palmerston North, New Zealand), pp. 119-124.

Frame, J., Charlton, J. F. I., \& Laidlaw, A. S. (1998). Temperate forage legumes. Wallingford: $\mathrm{CAB}$ international.

Frame, J., Harkess, R. D., \& Hunt, I. V. (1972). The effect of a ryegrass companion grass and the variety of red clover on the productivity of red-clover swards. Grass and Forage Science, 27, 241-250.

Gierus, M., Kleen, J., Loges, R., \& Taube, F. (2012). Forage legume species determine the nutritional quality of binary mixtures with perennial ryegrass in the first production year. Animal Feed Science and Technology, 172, 150-161.

Halling, M. A., Topp, C. F. E., \& Doyle, C. J. (2004). Aspects of the productivity of forage legumes in Northern Europe. Grass and Forage Science, 59, 331-344.

Hejduk, S., \& Knot, P. (2010). Effect of provenance and ploidity of red clover varieties on productivity, persistence and growth pattern in mixture with grasses. Plant, Soil and Environment, 56, 111-119.
Herrmann, D., Boller, B., Studer, B., Widmer, F., \& Kölliker, R. (2008). Improving persistence in red clover: Insights from QTL analysis and comparative phenotypic evaluation. Crop Science, 48, 269-277.

lepema, G., van Eekeren, N., \& van Dongen, M. (2006). Production and persistency of red clover (Trifolium pratense) varieties when grown in mixtures. Grassland Science in Europe, 11, 388-390.

Jacob I., Hartmann S., Schubiger F.X. and Struck C. (2015) Resistance screening of red clover cultivars to Colletotrichum trifolii and improving the resistance level through recurrent selection. Euphytica, 204, 303-310.

King, C., McEniry, J., Richardson, M., \& O'Kiely, P. (2012). Yield and chemical composition of five common grassland species in response to nitrogen fertiliser application and phenological growth stage. Acta Agriculturae Scandinavica, Section B - Soil \& Plant Science, 62, 644 658.

Kleen, J., Taube, F., \& Gierus, M. (2011). Agronomic performance and nutritive value of forage legumes in binary mixtures with perennial ryegrass under different defoliation systems. The Journal of Agricultural Science, 149, 73-84.

Laidlaw, A. S., \& McBratney, J. M. (1980). The effect of companion perennial ryegrass cultivars on red clover productivity when timing of the first cut is varied. Grass and Forage Science, 35, 257-265.

Lehmann, J., \& Briner, H.-U. (1998). Varieties of red clover and meadow fescue in tests. Agrarforschung, 5, 177-180.

Lüscher, A., Mueller-Harvey, I., Soussana, J. F., Rees, R. M., \& Peyraud, J. L. (2014). Potential of legume-based grassland-livestock systems in Europe: A review. Grass and Forage Science, 69, 206-228.

Marshall, A. H., Lowe, M., \& Vale, J. (2012). Improved persistence of red clover (Trifolium pratense L.) varieties in mixed swards. Grassland Science in Europe, 17, 73-75.

Marum, P., Smith, R. R., \& Grau, C. R. (1994). Development of procedures to identify red clover resistant to Sclerotinia trifoliorum. Euphytica, 77, 257-261.

Mela, T. (2003). Red clover grown in a mixture with grasses: Yield, persistence and dynamics of quality characteristics. Agricultural and Food Science in Finland, 12, 195-212.

Moharrery, A., Hvelplund, T., \& Weisbjerg, M. R. (2009). Effect of forage type, harvesting time and exogenous enzyme application on degradation characteristics measured using in vitro technique. Animal Feed Science and Technology, 153, 178-192.

Mytton, L. R., Cresswell, A., \& Colbourn, P. (1993). Improvement in soil structure associated with white clover. Grass and Forage Science, 48, 84-90.

Nyfeler, D., Huguenin-Elie, O., Suter, M., Frossard, E., \& Lüscher, A. (2011). Grass-legume mixtures can yield more nitrogen than legume pure stands due to mutual stimulation of nitrogen uptake from symbiotic and non-symbiotic sources. Agriculture, Ecosystems \& Environment, 140, 155-163.

Page, D., Dulclos, B., Aubert, G., Bonavent, J. F., \& Mousset-Declas, C. (1997). Sclerotinia rot resistance in red clover: Identification of RAPD markers using bulked segregant analysis. Plant Breeding, 116, 73-78.

Pérez-Harguindeguy, N., Díaz, S., Garnier, E., Lavorel, S., Poorter, H., Jaureguiberry, P., ... Urcelay, C. (2013). New handbook for standardised measurement of plant functional traits worldwide. Australian Journal of Botany, 61, 167-234.

Quesenberry, K. H., Baltensperger, D. D., Dunn, R. A., Wilcox, C. J., \& Hardy, S. R. (1989). Selection for tolerance to root-knot nematodes in red clover. Crop Science, 29, 62-65.

Rinne, M., \& Nykanen, A. (2000). Timing of primary growth harvest affects the yield and nutritive value of timothy-red clover mixtures. Agricultural and Food Science in Finland, 9, 121-134.

Rufelt, S. (1985). Selection for Fusarium root rot resistance in red clover. Annals of Applied Biology, 107, 529-534.

Schneider, C. A., Rasband, W. S., \& Eliceiri, K. W. (2012). NIH Image to ImageJ: 25 years of image analysis. Nature Methods, 9, 671-675. 
Taylor, N. L. (2008). A century of clover breeding developments in the United States. Crop Science, 48, 1-13.

Taylor, N. L., \& Quesenberry, K. H. (1996). Persistence. In R. J. Summerfield (Ed.), Red clover science (pp. 119-129). Dordrecht: Springer, Netherlands.

Tilley, J. M. A., \& Terry, R. A. (1963). A two-stage technique for the in vitro digestion of forage crops. Journal of the British Grassland Society, 18, 104-111.

Tucak, M., \& Popovic, S. (2013). Variation in yield, forage quality and morphological traits of red clover (Trifolium pratense L.) breeding populations and cultivars. Žemdirbystè-Agriculture, 100, 63-70.

Van Eekeren, N., Bommelé, L., Bloem, J., Schouten, T., Rutgers, M., de Goede, R., ... Brussaard, L. (2008). Soil biological quality after 36 years of ley-arable cropping, permanent grassland and permanent arable cropping. Applied Soil Ecology, 40, 432-446.

Van Eekeren, N., van Liere, D., de Vries, F., Rutgers, M., de Goede, R., \& Brussaard, L. (2009). A mixture of grass and clover combines the positive effects of both plant species on selected soil biota. Applied Soil Ecology, 42, 254-263.

Wilman, D., \& Altimimi, M. A. (1984). The in-vitro digestibility and chemical composition of plant parts in white clover, red clover and lucerne during primary growth. Journal of the Science of Food and Agriculture, 35, 133-138.

\section{SUPPORTING INFORMATION}

Additional Supporting Information may be found online in the supporting information tab for this article.

How to cite this article: Hoekstra NJ, De Deyn GB, Xu Y, Prinsen R, Van Eekeren N. Red clover varieties of Mattenklee type have higher production, protein yield and persistence than Ackerklee types in grass-clover mixtures. Grass Forage Sci. 2018;73:297-308. https://doi.org/10.1111/gfs.12307 